Primljen / Received: 25.1.2013.

Ispravljen / Corrected: 4.4.2013.

Prihvaćen / Accepted: 26.4.2013.

Dostupno online / Available online: 10.5.2013.

\section{Use of local aggregates in high modulus asphalt concrete layers}

Authors:

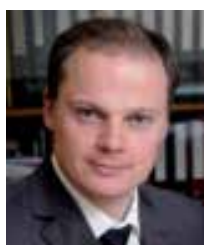

Assoc. Prof. Audrius Vaitkus, Ph.D. CE

Road Research Institute

Vilnius Gediminas Technical University

Lithuania

audrius.vaitkus@vgtu.It

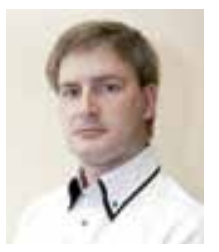

Viktoras Vorobjovas, Ph.D. CE

Road Research Institute

Vilnius Gediminas Technical University

Lithuania

viktoras.vorobjovas@vgtu.It

\section{Audrius Vaitkus, Viktoras Vorobjovas}

Professional paper

\section{Use of local aggregates in high modulus asphalt concrete layers}

High value of traffic flow influenced the need to build long lasting pavement structures with design life of more than 20-40 years. Current budget for maintenance and reconstruction is not sufficient for preventing the rutting on the existing asphalt pavement roads and streets. These factors lead to search for new materials, mixtures, and methods for preparation of asphalt mixes. The high modulus asphalt concrete is regarded as one of possible solutions. The laboratory study of the high modulus asphalt concrete with different types of bitumen binder and mineral aggregates is presented in the paper.

Key words:

high modulus asphalt concrete, asphalt pavement structure, rutting, stiffness modulus

Stručni rad

Audrius Vaitkus, Viktoras Vorobjovas

\section{Primjena lokalnih agregata za asfaltbetone visokih modula}

Povećanje intenziteta prometa uvjetuje izradu dugotrajnih kolničkih konstrukcija s vijekom trajanja od 20 do 40 godina. Sredstva koja su sada dostupna za održavanje i rekonstrukciju nisu dostatna za sprečavanje pojave kolotraga na postojećim cestama i ulicama s asfaltnom kolničkom konstrukcijom. Zbog tih se faktora istražuju novi materijali, mješavine i metode za izradu asfaltnih mješavina. Jedno od mogućih rješenja je i primjena asfaltbetona visokih modula. U radu su prikazana laboratorijska ispitivanja asfaltbetona visokih modula pri čemu su korištene razne vrste bitumenskih veziva i mineralnih agregata.

Ključne riječi:

asfaltbeton visokih modula, asfaltna kolnička konstrukcija, pojava kolotraga, modul krutosti

Fachbericht

Audrius Vaitkus, Viktoras Vorobjovas

\section{Anwendung lokaler Gesteinskörnungen für Hochmodul-Asphaltbetons}

Hohe Verkehrsflüsse haben zu dem Bedarf nach langanhaltenden Fahrbahnstrukturen mit einer Lebensdauer von sogar 20 - 40 Jahren beigetragen. Derzeitige Wartungsund Rekonstruktionsbudgets sind oft nicht ausreichend, um der Spurrinnenbildung auf verkehrsreichen Fahrbahnen mit herkömmlichen Asphaltschichten vorzubeugen. Diese Gegebenheiten führen zur verstärkten Erforschung neuer Materialien und Mischungen, sowie Methoden der Asphaltzubereitung. Die Anwendung von Hochmodul-Asphaltbeton kann als mögliche Antwort auf die erhöhten Anforderungen angesehen werden. In der vorliegenden Arbeit sind Laborprüfungen an Hochmodul-Asphaltbeton mit verschieden Bindemitteln aus Bitumen und mineralischen Gesteinskörnungen dargestellt.

Schlüsselwörter:

Hochmodul-Asphaltbeton, Asphaltaufbau, Spurrinen, Steifigkeitsmodul 


\section{Introduction}

In the period from 1990 to 2012, the number of vehicles in Lithuania increased 2.64 times, as did the traffic flow. Given the aforementioned, the asphalt pavement structures are designed and constructed to be thicker, which results in increased utilisation of road construction materials (mineral aggregates, bitumen binders, etc.) as well as in increased construction costs. The main problem is the lack of high quality construction materials in Lithuania, most of which are imported [1]. In addition, the costs are influenced by considerable transportation distances and the increasing bitumen prices.

Standard road construction methods require an appropriate amount of high quality materials. That is why the researchers all over the world are searching for the road construction materials, which could allow usage of reduced amount of lower quality materials [2-9].

During the last decade, in the Western Europe and all over the world, the usage of High Modulus Asphalt Concrete (HMAC) has increased. HMAC is described as having a very high resistance to rutting and fatigue cracking. HMAC could be used for the construction of asphalt binder and base layers. For this purpose, the special bitumen binders and the optimal composition of aggregates (which could consist of weaker mineral aggregates), are used [3-6, 8-18].

Viscous elastic properties of asphalt materials are significantly influenced by temperature. The temperature is a key factor for selecting the binder type for the asphalt mixture. The binder which is sufficiently stiff at high temperature often isn't elastic enough at low temperatures [2, 19-21]. Given the aforementioned, there is a need to research methods, which could ensure the proper pavement bearing capacity and durability, using the local materials and, also applying the new technologies in asphalt mixing. The response and degradation of pavements are most often forecast according to the results of laboratory testing, however, more reliable results could be obtained from field testing [22].

\section{High modulus asphalt concrete usage experience}

During the last decade, the researches proposed the long life pavement conception, according to which pavement structures have to be exploited for more than 40 years without any reconstruction. The main objective of long life pavement conception is to increase the stiffness and/or thickness of asphalt base and binder layers, and thus decrease pavement structure fatigue by reducing the tensile stress in the bottom of asphalt binder layer and compression stress in the top of the base layer. Those influences reduce distress in asphalt wearing layer [23]. HMAC was created and applied for the first time in France in 1980 during the reconstruction of roads with asphalt pavements, which were significantly distressed due rutted and cracked [3]. Two kinds of HMAC mixtures were used in France: Enrobe a Module Eleve (EVE) was used for the construction of asphalt base layers and Beton Bitumineaux a Module Eleve (BBME) was used for asphalt wearing layers. In addition, HMAC was used for asphalt base layers when the pavement was newly constructed (to achieve economic effect), when the thickness of asphalt pavement layers was reduced and weaker mineral aggregates were used. The results of HMAC exploitation test for the last 18 years were very good [3].

In Poland, the best results of resistance to rutting were obtained in HMAC with crushed gravel aggregates. Also, the minimal binder content should not be less than $5.0 \%$. Experimental research showed that pavement structures with HMAC meet the degradation requirements for low volume roads when the pavement structures were loaded after 200.000 cycles with $60 \mathrm{kN}$ load, after 100.000 with $80 \mathrm{kN}$ load and after additional 100.000 cycles with $80 \mathrm{kN}$ load [4]. In 2008 in Brazil, the research of HMAC with basalt, sand, dolomite fines and asphaltic modified binder showed good results and the advantage over the traditional hot mix asphalt [13]. The HMAC research, when the reclaimed asphalt was used for mixing, showed that stiffness was increasing, but the fatigue resistance was decreasing. Nevertheless, the fatigue resistances of all the tested HMAC were higher than that of the ordinary hot mix asphalt [12]. The research and analysis made by Elliott [5] using the HMAC for the construction of asphalt base layers showed that this technology is neutral or negative when it comes to cost-effectiveness. However, when counting only the expenditures and pavement durability for the long time period, it becomes satisfactory.

The usage of polymer modified 20/30 bitumen increases the HMAC stiffness at low temperature. The HMAC dynamic modulus at high temperatures is $50 \%$ higher than the ordinary hot mix asphalt. Rutting resistance of HMAC is twice higher than that of hot mix asphalt, and the fatigue resistance is 5-10 times higher [15]. The research of HMAC at low temperature, made by Jaczewski [24] in Poland, showed that the mechanical characteristics of HMAC with polymer modified bitumen are better than HMAC with non-modified bitumen and hot mix asphalt. The research of Sybilski et al. [9] showed that the limestone minerals could be suitable for HMAC aggregate. The usage of HMAC in asphalt pavement structure allows reduction in comparative deformations and to slower deformation timing, at the same time increasing rutting resistance and durability [16].

\section{Design of high modulus asphalt concrete with local aggregates}

In general, HMAC mixtures are used for the construction of asphalt base and binder layers. The asphalt layers' construction requirements of the Lithuanian road pavement 
Table 1. Types and components of asphalt mixtures

\begin{tabular}{|c|c|c|c|}
\hline Bitumen & Aggregate & Crushed granite & Crushed dolomite \\
\hline PMB 45/80-55 & AC16AS G & AC16AS D & AC16AS GR \\
\hline $20 / 30$ & AC16HMAC G & AC16HMAC D & AC16HMAC GR \\
\hline PMB 25/55-60 & AC16HMAC G PMB & AC16HMAC D PMB & AC16HMAC GR PMB \\
\hline
\end{tabular}

structure IT ASFALTAS 08 require that the asphalt concrete $A C 16$ AS has to be used for the construction of the roads with pavement structure class SV and I-III for the asphalt binder layers. Most often, AC 16 AS includes the polymer modified bitumen PMB 45/80-55. The asphalt base layer is most often constructed from asphalt concrete AC 22 PS and bitumen $50 / 70$.

The laboratory research, described in this article, was performed at the Road Research Institute of Vilnius Gediminas Technical University. For the laboratory testing, the asphalt concrete AC 16 AS was chosen as a comparable mix. For its production, the granite aggregates and polymer modified bitumen PMB 45/80-55 were used. In order to evaluate the influence of different mineral aggregates on HMAC physical and mechanical properties, several mixtures were designed, produced and tested on AC 16 AS basis. The crushed dolomite and gravel aggregates were used for their production. Table 1 shows all the designed and laboratory produced asphalt mixtures with different aggregates and bitumen. The asphalt mixtures aggregate size distribution (dependent on aggregate type) is showed in Figures 1 and 2.

HMAC mixtures were produced with two kinds of bitumen: 20/30 and polymer modified bitumen PMB 25/55-60. The quantity of bitumen for the HMAC was chosen in order to get air voids content in range from $2.0 \%$ to $4.0 \%$. Marshall specimens from each mixture were formed according to standard LST EN 12697-30 and specimens prepared by roller compactor were formed according to standard LST EN 1269733.

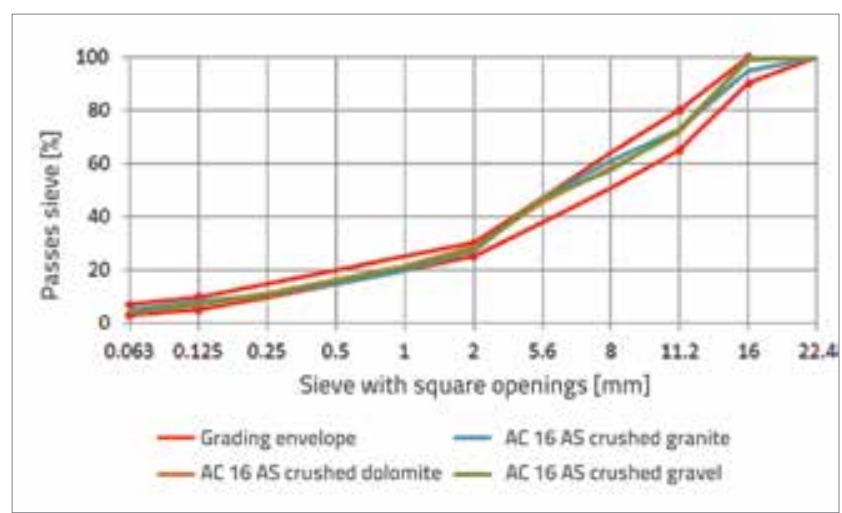

Figure 1. Volumetric grading curves of asphalt concrete AC 16 AS mixtures
Analysis of mixtures produced in laboratory showed the following physical and mechanical characteristics:

- Stiffness modulus, $10^{\circ} \mathrm{C}$, according to LST EN 12697-26 (ITCY);

- Resistance to rutting, $60^{\circ} \mathrm{C}$ and 10000 cycles, according to LST EN 12697-22;

- Fatigue resistance $4 \mathrm{~PB}-\mathrm{PR}, 10^{\circ} \mathrm{C}$ and $10 \mathrm{~Hz}$, according to LST EN 12697-24;

- Asphalt mixture density, according to LST EN 12697-5;

- Asphalt mixture bulk density, according to LST EN 12697-6;

- Air voids content, according to LST EN 12697-8;

- Stability and flow, $60^{\circ} \mathrm{C}$, according to LST EN 12697-34. This test was performed for two groups of samples: the first group of samples was prepared by $2 \times 50$ blows, the second by $2 \times 75$ blows.

In some countries (Poland, etc.), HMAC samples are prepared by $2 \times 75$ blows (Marshall specimens are prepared by $2 \times 50$ blows), but the LST EN 12697-30 standard requires $2 \times 50$ blows. In order to get a more comparable data, Marshall specimens for the experiment were prepared by $2 \times 50$ and $2 \times 75$ blows. Marshall specimens prepared by different number of blows were used to measure bulk density and air void. Table 2 shows the results of the laboratory experiment. Poland has the technical document and requirements for HMAC. Due to similar climatic conditions in Lithuania and Poland, it was decided to compare the obtained results with the requirements for HMAC according to Poland's technical document.

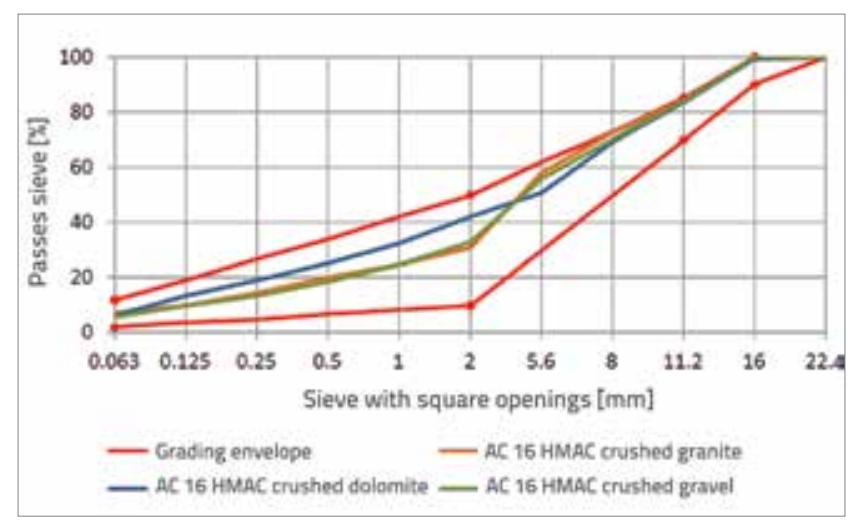

Figure 2. Volumetric grading curves of HMAC mixtures 
Table 2. Results of physical and mechanical properties of HMAC and hot mix asphalt

\begin{tabular}{|c|c|c|c|c|c|c|c|c|c|c|}
\hline $\begin{array}{l}\text { Properties of asphalt } \\
\text { mixtures }\end{array}$ & Ũ & 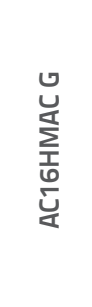 & 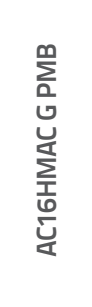 & 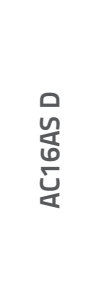 & 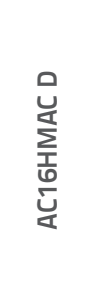 & 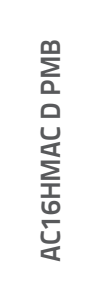 & $\begin{array}{l}\text { 똔 } \\
\text { ữ } \\
\underline{\underline{U}}\end{array}$ & 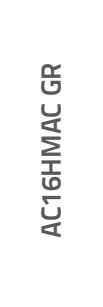 & 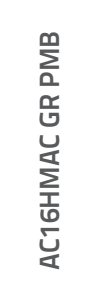 & 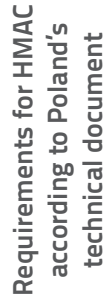 \\
\hline Binder content [\%] & 4,5 & 4,0 & 4,0 & 4,8 & 4,0 & 4,1 & 4,8 & 4,0 & 4,0 & 4,8 \\
\hline $\begin{array}{l}\text { Asphalt mixture density } \\
{\left[\mathrm{kg} / \mathrm{m}^{3}\right]}\end{array}$ & 2538 & 2503 & 2517 & 2531 & 2550 & 2534 & 2498 & 2512 & 2502 & - \\
\hline $\begin{array}{l}\text { Asphalt mixture } \\
\text { bulk density } \\
(2 \times 50 \text { blows })\left[\mathrm{kg} / \mathrm{m}^{3}\right]\end{array}$ & 2439 & 2416 & 2457 & 2477 & 2477 & 2479 & 2431 & 2449 & 2417 & - \\
\hline Air voids content [\%] & 3,90 & 3,48 & 2,38 & 2,13 & 2,86 & 2,17 & 2,68 & 2,51 & 3,40 & $2,0-4,0$ \\
\hline $\begin{array}{c}\text { Stability } \\
(2 \times 50 \text { blows })[\mathrm{kN}]\end{array}$ & 13,5 & 34,0 & 22,9 & 24,1 & 47,4 & 27,3 & 18,8 & 33,9 & 29,1 & - \\
\hline $\begin{array}{c}\text { Flow } \\
(2 \times 50 \text { blows })[\mathrm{mm}]\end{array}$ & 2,9 & 1,7 & 3,3 & 3,0 & 1,6 & 2,5 & 2,9 & 2,3 & 2,1 & - \\
\hline $\begin{array}{c}\text { Asphalt mixture } \\
\text { bulk density } \\
\left(2 \times 75 \text { blows) }\left[\mathrm{kg} / \mathrm{m}^{3}\right]\right.\end{array}$ & 2451 & 2424 & 2478 & 2487 & 2478 & 2488 & 2455 & 2454 & 2431 & - \\
\hline Air voids content [\%] & 3,43 & 3,16 & 1,55 & 1,74 & 2,82 & 1,82 & 1,72 & 2,31 & 2,84 & $2,0-4,0$ \\
\hline $\begin{array}{c}\text { Stability } \\
(2 \times 75 \text { blows })[k N]\end{array}$ & 18,9 & 37,8 & 25,3 & 25,5 & 49,3 & 29,8 & 27,5 & 36,0 & 30,6 & - \\
\hline $\begin{array}{c}\text { Flow } \\
(2 \times 75 \text { blows })[\mathrm{mm}]\end{array}$ & 2,5 & 2,0 & 2,8 & 2,9 & 1,7 & 2,6 & 2,6 & 2,3 & 2,6 & - \\
\hline $\begin{array}{l}\text { Relative rut depth } \\
{[\%]}\end{array}$ & 3,8 & 1,9 & 1,3 & 4,5 & 2,4 & 2,8 & 4,1 & 2,2 & 1,9 & $\leq 5,0$ \\
\hline Fatigue $\left[\varepsilon_{6}\right]$ & 19 & 22 & 34 & 25 & 21 & 23 & 19 & 9 & 19 & $\geq 130$ \\
\hline Stiffness [MPa] & 14381 & 17520 & 18357 & 15389 & 25718 & 19737 & 16116 & 22021 & 17298 & $\geq 14000$ \\
\hline
\end{tabular}

\section{Analysis and evaluation of results}

The Marshall stability of all the tested asphalt mixtures varied from $13.5 \mathrm{kN}$ to $49.3 \mathrm{kN}$. The experiment showed that the highest Marshall stability is achieved with stiff bitumen 20/30 (Figure 3). The Marshall stability was the highest (47.4 MPa) for asphalt concrete, which was prepared with crushed dolomite aggregates and binder 20/30 (AC16HMAC D). Marshall stability of specimens, which were prepared with polymer modified binder PMB 45/80-55, was also the highest (24.1 MPa, with dolomite aggregate (AC16AS D)). The results showed that Marshall stability of specimens with polymer modified binder PMB 45/80-55 varied up to $16 \%$, of which specimens with crushed dolomite aggregate (AC16HMAC GR PMB) varied by $6 \%$. Marshall stability of specimens compacted by $2 \times 75$ blows, was higher $(11.8 \%)$ than of specimens compacted by $2 \times 50$ blows, but the distribution of highest and lowest values dependent on the asphalt mix type was very significant.
The Marshall flow results of asphalt mixture specimens are shown in Figure 4. The laboratory research demonstrated that the lowest flow $(1.6 \mathrm{~mm})$ was measured in specimens AC16HMAC with crushed dolomite aggregate and 20/30 bitumen binder (AC16HMAC D). The highest flow $(3.3 \mathrm{~mm}$ ) was measured in AC16HMAC with granite aggregate and PMB 25/55-45 binder (AC16HMAC G PMB). Furthermore, it was determined that the flow of asphalt specimens with bitumen binder $20 / 30$ was $45 \%$ lower than that of other specimens.

Asphalt rutting resistance testing showed that the relative rut depth of all specimens was lower than $5 \%$ (Figure 5). The laboratory experiment showed that the relative rut depth of asphalt specimens varied from $1.3 \%$ to $4.5 \%$. The lowest relative asphalt specimens rut depth $(1.3 \%)$ was obtained by using the granite mineral aggregate and polymer modified bitumen (PMB 25/55-60). It should be emphasied that the lowest rut depth was measured in specimens with stiffer 


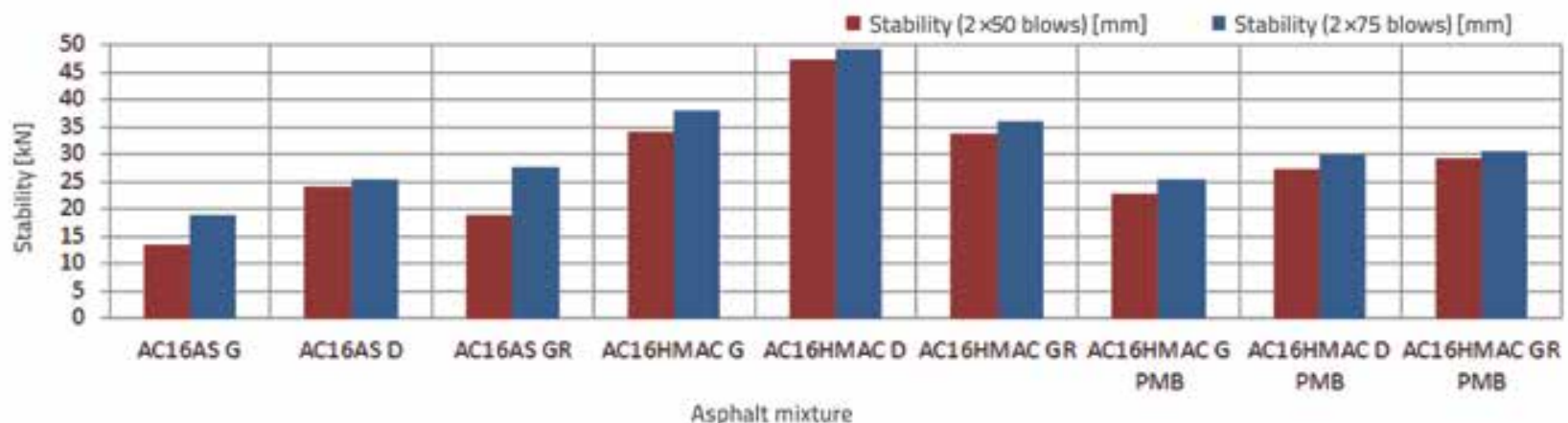

Figure 3. Distribution of Marshall stability

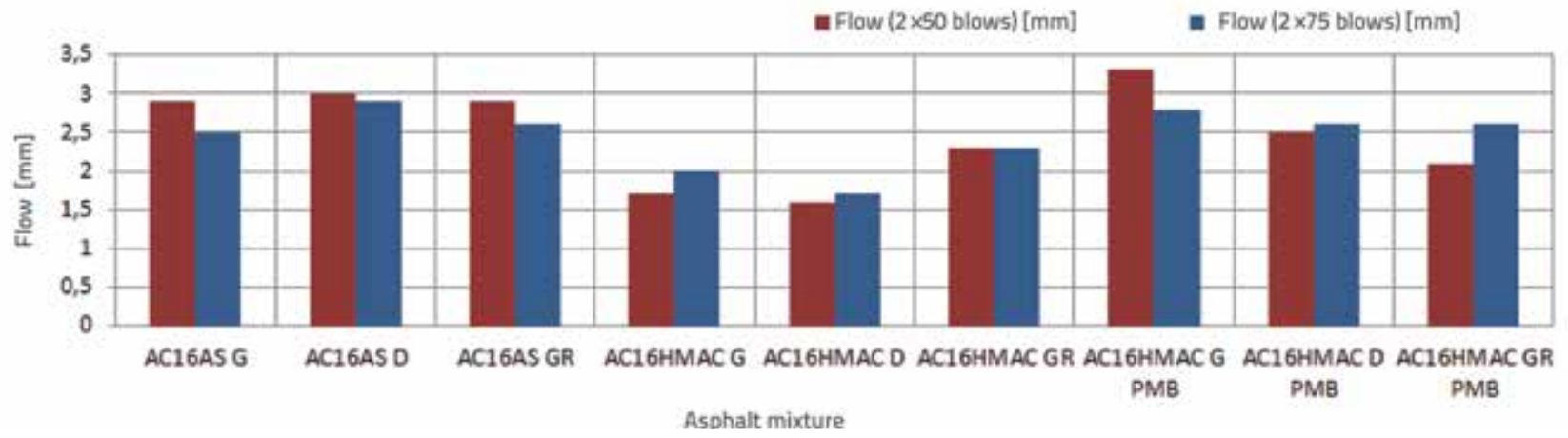

Figure 4. Distribution of Marshall flow

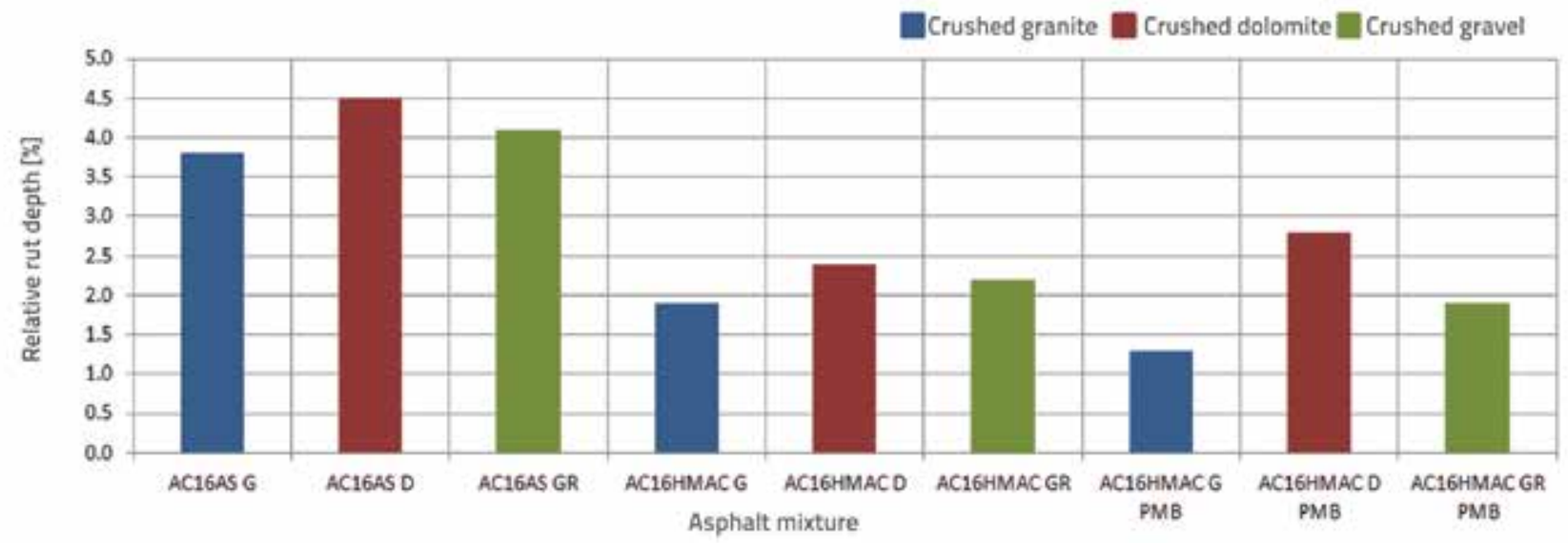

Figure 5. Distribution of relative rut depth, after loading 10.000 cycles

polymer modified bitumen and crushed dolomite aggregates. Without reference to type of aggregate, the relative rut depth was lower in those specimens with stiffer bitumen (20/30 and PMB 25/55-60) than in those with PMB 45/80-55 bitumen, the lowest relative rut depth was obtained in specimens with binder PMB 25/55-60, except for specimens with crushed dolomite aggregates.

Figure 6 shows relative rut depth growth scenario which presents the character of rutting. The rutting was faster at first 500 cycles in asphalt concrete with dolomite and crushed gravel, but from 500 to 10000 cycles, the graphs for all AC were quite similar. The rutting of AC16HMAC D PMB was also faster at first 500 cycles, but not that of AC16HMAC D. The deepest rutting was measured in asphalt concrete (AC 16 AS) samples with binder PMB 45/80-55.

The results of HMAC fatigue resistance are presented in Figure 7. It is obvious that the results of laboratory prepared asphalt mixtures fatigue resistance don't meet the requirements of Polish standards for HMAC mixes $\left(>130 \varepsilon_{6}\right)$. The highest fatigue resistance value $\left(34 \varepsilon_{6}\right)$ was measured in asphalt concrete with granite mineral aggregate and stiff bitumen PMB 25/55-60, and the lowest fatigue resistance value $\left(9 \varepsilon_{6}\right)$ was measured in AC16HMAC GR specimens with bitumen binder 20/30. But otherwise, in the crushed dolomite and gravel mineral 

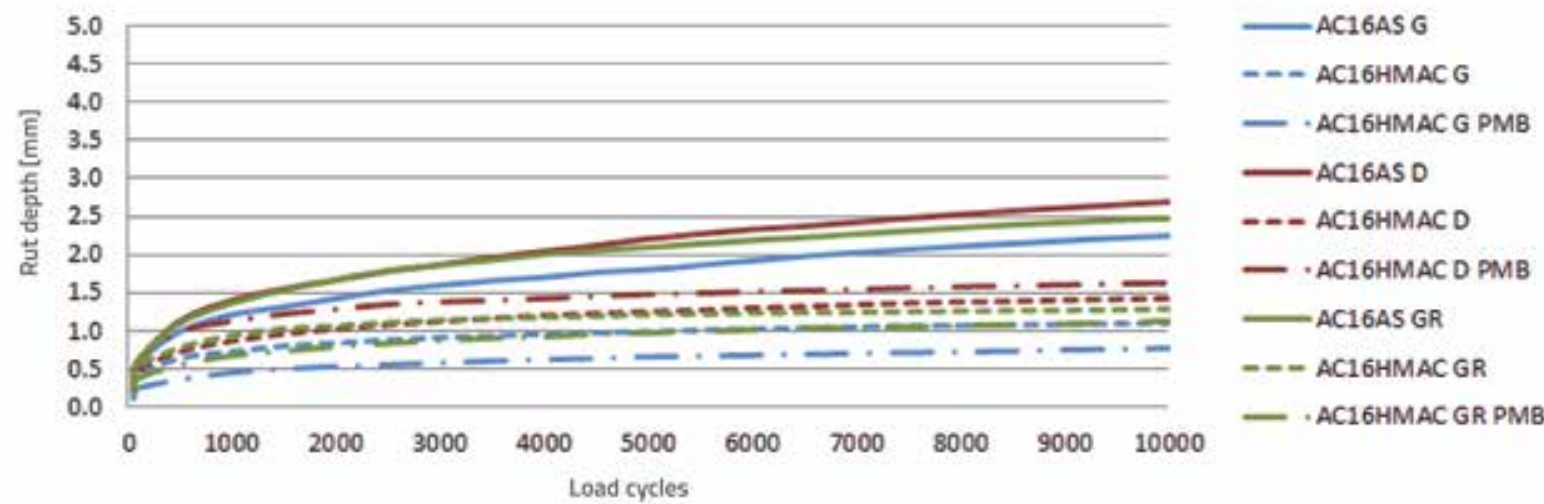

Figure 6. Rut depth growth scenario

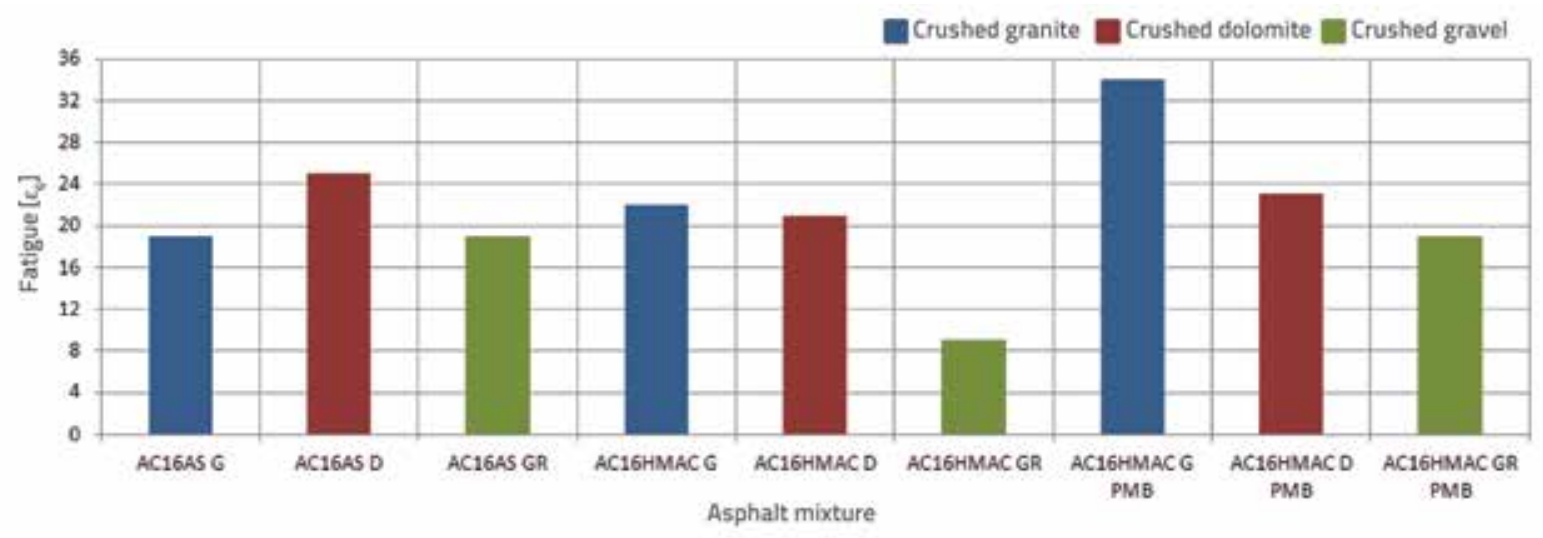

Figure 7. Distribution of fatigue resistance

aggregate mixes, the higher fatigue resistance was measured in asphalt concrete with bitumen PMB 45/80-55 specimens than in those specimens with binder PMB 25/55-60. The lowest fatigue resistance was measured in specimens with crushed gravel mineral aggregates.

Figure 8 shows the results of asphalt concrete stiffness modulus. The experiment revealed that the highest stiffness modulus (25718 MPa) is that of AC16HMAC D and the lowest is that of AC16AS G (14381 MPa). In mixtures with stiff bitumen (20/30, PMB 25/55-60) the highest stiffness modulus were in asphalt concrete specimens with dolomite mineral aggregates. The stiffness modulus of specimens with bitumen $20 / 30$ was $18 \%$ higher than in those with PMB 25/5560 , except for asphalt concrete mixtures with granite mineral aggregates. The stiffness modulus of all asphalt concrete specimens was higher than $14.000 \mathrm{MPa}$, and thus it satisfied the Polish standard requirements for HMAC mixtures. The stiffness modulus of asphalt concrete specimens with stiff bitumen was higher than 16.000 MPa.

The fatigue resistance of asphalt concrete specimens mixed in laboratory was relatively small and doesn't meet either the Polish standard requirements for the high modulus asphalt or

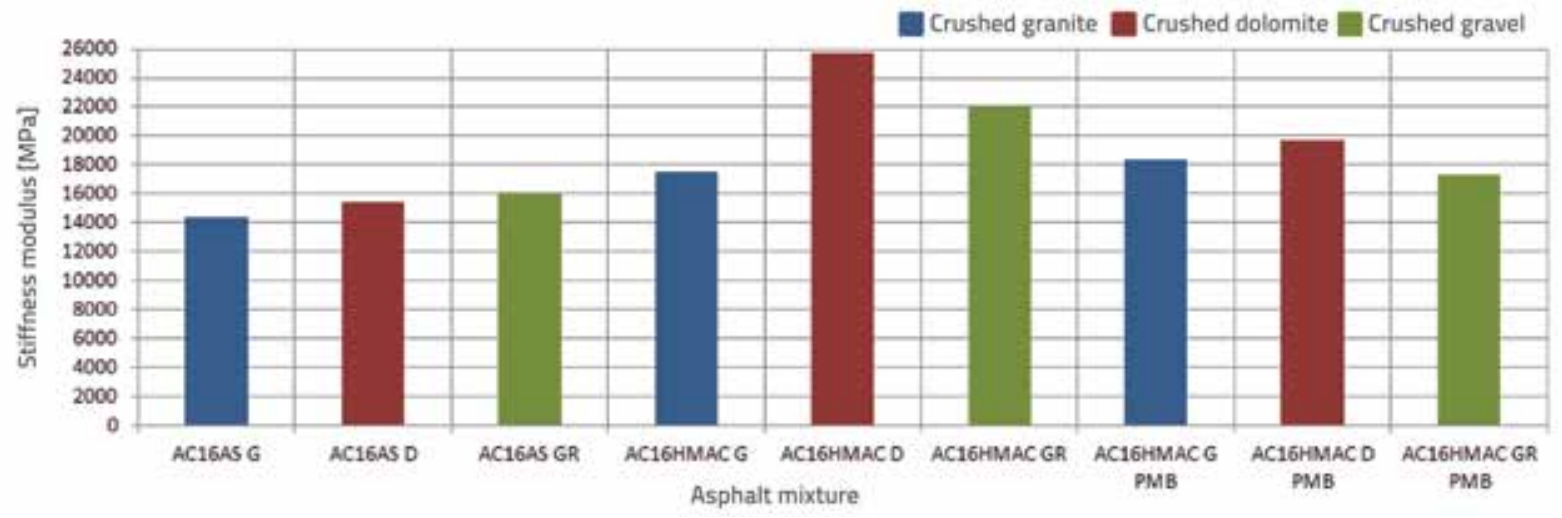

Figure 8. Distribution of stiffness modulus 
the experience of other countries. The main reason could be the low quantity of bitumen binder, but usually in the laboratory, the high modulus asphalt concrete mixtures are designed under condition that air void contact must vary from $2.0 \%$ to $4.0 \%$. In addition, there is also a possibility that inappropriate composition of asphalt concrete mixtures, where the part of laboratory prepared mixtures mineral aggregate was sand fraction $0 / 2$, was used. Analysis of HMAC design composition in other European countries showed that these mixtures are prepared from $100 \%$ crushed aggregate and sand is not used.

\section{Conclusions}

The highest Marshall stability is achieved with stiff bitumen. The Marshall stability was the highest (47.4 MPa) in HMAC with crushed dolomite aggregates and binder 20/30 (AC16HMAC D). The number of blows of Marshal specimens' compaction doesn't influence the Marshal stability, the difference is up to $7 \%$.

The lowest flow $(1.6 \mathrm{~mm})$ was measured in HMAC with crushed dolomite aggregate and 20/30 bitumen binder (AC16HMAC D). The highest flow $(3.3 \mathrm{~mm}$ ) was measured in HMAC with granite aggregate and PMB 25/55-45 binder (AC16HMAC G PMB).

The relative rut depth of all specimens was lower than $5 \%$. The lowest value $(1.3 \%)$ was obtained in HMAC with crushed granite mineral aggregate and PMB 25/55-60. Independently from HMAC, aggregate type relative rut depth is up to 1.3$4.5 \%$ lower than that of the asphalt concrete.

\section{REFERENCES}

[1] Skrinskas, S., Gasiūnienè, V. E., Laurinavičius, A., Podagèlis, I.: Lithuanian Mineral Resources, Their Reserves and Possibilities for Their Usage in Road Building, The Baltic Journal of Road and Bridge Engineering, 5(4), pp. 218-228, 2010.

[2] Čygas, D., Laurinavičius, A., Vaitkus, A., Perveneckas, Z., Motiejūnas, A.: Research of Asphalt Pavement Structures on Lithuanian Roads (I), The Baltic Journal of Road and Bridge Engineering, 3(2), pp. 77-83, 2008.

[3] Corte, J.: Development and Uses of Hard-Grade Asphalt and of High-Modulus Asphalt Mixes in France, Transportation Research Circular 5003: Perpetual Bituminous Pavements, pp. 12-30, 2003.

[4] Bankowski, W, Tusar, M., Wiman, L. G., Sybliski, D., Gajewski, M., Horodecka, R., Maliszewski, M., Mirski, K.: Laboratory and Field Implementation of High Modulus Asphalt Concrete. Requirements for HMAC Mix Design and Pavement Design, European Commission, Sixth Framework Programme, Sustainable Surface Transport, 63 p., 2009.
The rutting was faster at first 500 cycles in asphalt concrete with crushed dolomite and crushed gravel, but from 500 to 10000 cycles, the graphs for all AC were quite similar. The lowest rut depth $(0.77 \mathrm{~mm})$ after 10000 cycles was obtained in HMAC with crushed granite mineral aggregate and PMB 25/55-60.

The highest stiffness modulus is that of AC16HMAC D (25718 MPa) and the lowest is that of AC16AS G (14381 MPa). In mixtures with stiff bitumen (20/30, PMB 25/55-60) the highest stiffness modulus were measured in asphalt concrete specimens with dolomite mineral aggregates. The stiffness modulus of specimens with bitumen $20 / 30$ was $18 \%$ higher than of those with PMB 25/55-60, except for asphalt concrete mixtures with granite mineral aggregates.

The HMAC with stiffer aggregate (granite) is more resistant to rutting and fatigue. But the HMAC with less stiffer aggregates (dolomite, gravel) also showed good results compared to asphalt concrete. It could be stated that the HMAC physical and mechanical properties are influenced by the kind of aggregate but even more influenced by the kind of bitumen. It is recommended to use polymer modified bitumen in HMAC base layers and only polymer modified bitumen in HMAC binder layers, as they are more resistant to fatigue and less susceptible to temperature.

The $5.0 \%$ of bitumen content in HMAC is strongly recommended. The lower bitumen content could significantly reduce the fatigue resistance and durability of HMAC pavement structure.
[5] Elliott, R.: Implementing High Modulus Asphalt Technology in The United Kingdom, The Internation Seminar Maintenance Techniques to Improve Pavement Performance, 10 p, 2009.

[6] Tusar, M., Turk, M. R., Bankowski, W., Wiman, L. G., Kalman, B.: Evaluation of Modified Bitumen, High Modulus Asphalt Concrete and Steel Mesh as Materials for Road Upgrading, in Proccedings of the 7th International RILEM Symposium on Advanced Testing and Characterisation of Bituminous Materials, pp. 443-452, 2009.

[7] Vaitkus, A., Čygas, D., Laurinavičius, A., Perveneckas, Z.: Analysis and Evaluation of Possibilities for the Use of Warm Mix Asphalt in Lithuania, The Baltic Journal or Road and Bridge Engineering, 4(2), pp. 80-86, 2009.

[8] Celauro, C., Bernardo, C, Gabriele, B.: Production of Innovative, Recycled and High-Performance Asphalt for Road Pavements, Resources, Conservation and Recycling, 54, pp. 337-347, 2010. 
[9] Sybilski, D., Bankowski, W., Krajewski, M.: High Modulus Asphalt Concrete with Limestone Aggregate, International Journal of Pavement Research and Technology, 3(2), pp. 96-101, 2010.

[10] Santos, L. P., Capitao, S. D., Pais, J. C.: Stiffness Modulus and Phase Angle Prediction Models For High Modulus Asphalt Concrete, International Journal of Pavements, 2(2), pp. 37-49, 2003.

[11] Maupin, G. W., Diefenderfer, B. K.: Design of High-BinderHigh-Modulus Asphalt Mixture, Final Report VTRC 07R15, Virginia Transportation Research Council, 28 p., 2006.

[12] De Backer, C., De Visscher, J., Glorie, L., Vanelstraete, A., Vansteenkiste, S., Heleven, L.: A Comparative Highmodulus Asphalt Experiment in Belgium, in Proccedings of Transport Research Arena, 6 p., 2008.

[13] Rohde, L., Ceratti, J. A. P., Nunez, W. P., Vitorello, T.: Using APT and Laboratory Testing to Evaluate the Performance of High Modulus Asphalt Concrete for Base Courses in Brazil, in Procceding of the 3rd Internation Conference on Impacts and Benefits from APT Programs, 11 p, 2008.

[14] Vervaecke, F., Maeck, J., Vanelstraete, A.: Comparison of the Modulus of High-modulus Asphalt Mixtures - Experimental Determination and Calculation, in Proccedings of the 6th RILEM International Conference on Cracking in Pavements, pp. 491-499, 2008.

[15] Lee, H. J., Lee, J. H., Park, H. M.: Performance Evaluation of High Modulus Asphalt Mixtures for Long Life Asphalt Pavements, Construction and Building Materials 21, pp. 1079-1087, 2007.

[16] OuYang, W., Yu, G., Zhu, F.: Research on Anti-Rutting Performance of High Modulus Asphalt Concrete Pavement, Advanced Materials Research, 163-167, pp. 4474-4477, 2011.
[17] Xiushan, W., Tuanjie, C., Xiaojun, D.: Analysis of the Mechanical Impact of High-Modulus Asphalt Concrete on Road Structure, Applied Mechanics and Materials, 97-98, pp. 334-339, 2011.

[18] Yunliang, L., Yiqiu, T., Liang, M.: Application Study on High Modulus Asphalt Concrete in Bridge Pavement, Advanced Materials Research, 243-249, pp. 4244-4247, 2011.

[19] Čygas, D.; Laurinavičius, A.; Vaitkus, A.; Paliukaitè, M.; Motiejūnas, A.: A Test Road Section of Experimental Pavement Structures in Lithuania (II), The 8th International Conference Environmental Engineering, pp. 1064-1069, 2011.

[20] Motiejūnas, A., Paliukaitè, M., Vaitkus, A., Čygas, D., Laurinavičius, A.: Research on The Dependence of Asphalt Pavements Stiffness Upon The Temperature of Pavement Layers, The Baltic Journal of Road and Bridge Engineering, 5(1), pp. 50-54, 2010.

[21] Paliukaitè, M., Vaitkus, A.: Analysis of Temperature and Moisture Influence on Asphalt Pavement Strength, The 8th International Conference Environmental Engineering, pp. 1160-1165, 2011.

[22] Vaitkus, A., Laurinavičius, A., Oginskas, R., Motiejūnas, A., Paliukaitè, M., Barvidienè, O.: The Road of Experimental Pavement Structures: Experience of Five Years Operation, The Baltic Journal of Road and Bridge Engineering, 7(3), pp. 220-227, 2012.

[23] Nunn, M.: Long-life Flexible Roads, The 8th International Conference on Asphalt Pavements, pp. 3-16, 1997.

[24] Jaczewski, M.: Evaluation of Low Temperature Behaviour of High Modulus Aspalt Mixes, Abstract for YEAR2010 Design and Production of Vehicles and Infrastructure, 2 p. 2010. 